\title{
Eurasianisme dan Kebijakan Luar Negeri Rusia
}

\author{
Leonard F. Hutabarat \\ Kepala Pusat P2K2 Amerika dan Eropa \\ Kementerian Luar Negeri Republik Indonesia \\ Email : lfhutabarat@gmail.com
}

\begin{abstract}
Abstrak
Keterlibatan Rusia dalam integrasi Eurasia menunjukkan tantangan yang dihadapi Rusia di Asia. Rusia perlu membangun kembali pengaruh ekonomi dan politiknya di kawasan guna mempertahankan dorongan integrasinya ke kawasan Timur, termasuk membangun jembatan menuju arah tenggara ke China dan Asia Pasifik. Dalam konteks ini, hakekat kebijakan kerjasama Rusia merupakan conditio sine qua non bagi terwujudnya Eurasian Economic Union tahun 2015. Artikel ini menjelaskan kebijakan integrasi Rusia dalam hubungannya ke dan di luar Asia Tengah, ke arah Asia sebagai sebuah benua. Integrasi kawasan adalah suatu ide yang sangat populer, dengan potensi keuntungan-keuntungan ekonomi dan meningkatnya pengaruh internasional. Langkah-langkah signifikan dilakukan dengan membentuk Eurasian Economic Union. Namun demikian, untuk mengimplementasikan inisiatif regionalnya dan menjadi aktor yang lebih diperhitungkan dalam institusi-institusi multilateral regional, Rusia harus mengatasi baik keterbatasan-keterbatasan domestik maupun internasional yang dihadapinya. Alienasi Rusia saat ini dari Barat dan semakin meningkatnya ketergantungan terhadap China mungkin akan mendorong Rusia dengan aktif melakukan upaya-upaya yang lebih baik dalam memenuhi misi ini.
\end{abstract}

Kata kunci : eurasia, eurasian economic union, integrasi regional, rusia

\begin{abstract}
Russia's engagement in Eurasian integration highlights the challenges that Russia faces in Asia. Russia needs to re-establish political and economic influence in the region to maintain her eastward-focused integration drive, including building a southeastwards bridge to China and Asia Pacific. In this context, the cooperative nature of Russian policies is the conditio sine qua non for the establishment of the Eurasian Economic Union in 2015. This article examines Russia's integration policy in relation to Central Asia and beyond, towards Asia as a continent. Regional integration is very much a popular idea, with the potential for economic benefits and increased international influence. Significant steps were taken towards the creation of the Eurasian Economic Union. However, to implement its regional initiatives and to become a more visible player in the regional multilateral institutions, Russia will have to overcome both domestic and international limitations it faces. Russia's current alienation from the West and its growing dependency on China may push the country to actively seek better ways to accomplish this mission.
\end{abstract}

Keywords : eurasia, eurasian economic union, regional integration, russia

\section{Pendahuluan}

Rusia $^{1}$ memainkan peran yang signifikan dalam proses integrasi Eurasia.

\footnotetext{
${ }^{1}$ Rusia atau secara resmi dikenal sebagai Federasi Rusia secara geografis adalah negara yang membentang dengan luas di sebelah timur Eropa dan utara Asia. Dengan wilayah seluas 17.125.200 km², Rusia adalah negara terluas di dunia. Wilayahnya mencakup seperdelapan luas daratan bumi, penduduknya menduduki peringkat kesembilan terbanyak di dunia dengan jumlah sekitar 146 juta jiwa (Februari 2017. Dapat diunduh
}

$$
\begin{aligned}
& \text { Survey opini publik yang dilakukan } \\
& \text { Integration Barometer menunjukkan Rusia }
\end{aligned}
$$

pada http://www.eaeunion.org/?lang=en\#aboutcountries. Diakses tanggal 12 Februari 2017). Wilayahnya membentang sepanjang Asia Utara dan sebagian Eropa timur, Rusia memiliki 11 zona waktu dan wilayahnya terdiri dari berbagai tipe lingkungan dan tanah. Dari barat laut sampai ke tenggara, Rusia berbatasan dengan Norwegia, Finlandia, Estonia, Latvia, Lituania dan Polandia (keduanya berbatasan dengan Kaliningrad Oblast), Belarusia, Ukraina, Georgia, Azerbaijan, Kazakhstan, Tiongkok, Mongolia, dan Korea Utara. Negara ini berbatasan laut dengan Jepang di Laut Okhotsk dan Negara Bagian Alaska, Amerika Serikat di Selat Bering. 
secara konsisten dipandang sebagai pemersatu negara-negara Commonwealth of Independent States (CIS). ${ }^{2}$ Negara anggota CIS percaya bahwa kepentingan nasional negara anggota yang berpartisipasi dalam integrasi Eurasia akan diakomodir. Kebanyakan mayoritas negara republik pasca Soviet bergantung pada Rusia dalam hal solidaritas politik dan bantuan militer. Persepsi populer terhadap Rusia sebagai "centre of gravity" tidak hanya luasnya wilayah dan besarnya sumber daya alam Rusia. Karakter Eurasia Rusia juga menjadikannya entitas ethnographic yang unik dengan konsep ideologi, politik, sejarah dan budaya. Konsep karakter Eurasia merujuk pada akhir abad ke15 dan awal abad ke-16 saat orang Rusia mulai mengidentifikasi dirinya sebagai pembela Ortodoks dan pewaris Byzantine Culture yang kemudian berkembang pada pemikiran filosofis dan sejarah yang berkontribusi pada pembentukan pandangan geopolitik Eurasianist. $^{3}$

Banyak pemikir Rusia yang menyuarakan pembangunan ekonomi Rusia dan Eurasia setelah bubarnya Uni Soviet pada awal dekade 1990-an menyatakan Rusia akan

\footnotetext{
2 Integration Barometer, Centre for Integration Studies, Eurasian Development Bank, Moscow, 2012, 2013. Commonwealth of Independent States (CIS) dibentuk tahun 1991 dan beranggotakan Armenia, Azerbaijan, Belarusia, Georgia (keluar tahun 2008), Kazakhstan, Kyrgyzstan, Moldova, Rusia, Tajikistan, Turkmenistan, Ukraina, dan Uzbekistan.

${ }^{3}$ Sergei Glazyev "Russia and the Eurasian Union", dalam Piotr Dutkiewicz and Richard Sakwa (Eds), Eurasian Integration - The View From Within, Routledge, Oxford, 2015, p. 84.
}

bertahan sebagai Eurasian power dan hanya melalui Eurasianism. Para pendukung Eurasia juga meyakini kesejahteraan negara-negara di Eropa Timur, Kaukasus dan Asia Tengah tidak didasarkan pada apakah mereka ingin bekerjasama dengan Barat atau Timur, namun lebih pada mewujudkan Eurasian trascontinental corridor dari Atlantik hingga Pasifik. Rusia adalah negara yang terbentang dari laut di Timur Eropa hingga laut di Utara Asia serta Selat Bering di Negara Bagian Alaska, Amerika Serikat, yang dapat memfasilitasi komunikasi antara tiga zona teknologi dan ekonomi global di Eropa Barat, Asia Timur dan Amerika Utara. Artikel ini akan membahas latar belakang upaya Rusia melakukan integrasi di kawasan Eurasia, bagaimana kebijakan luar negeri Rusia terhadap Eurasianisme serta peluang dan tantangan yang dihadapi Rusia dalam integrasi ke kawasan Asia Timur.

\section{Rusia dan Integrasi Eurasia}

Rusia memiliki peran unik dalam konteks integrasi Eurasia berdasarkan beberapa hal. Pertama, Rusia tidak hanya sebuah negara, namun juga sebuah peradaban. China, India dan Jepang juga dapat melakukan klaim yang sama dalam hal ini terkait sudut pandang sosial budaya dan sejarah. Kedua, Rusia juga terletak secara geografis sebagai pusat Eurasia, yang menghubungkan kawasan timur, barat dan selatan. Ketiga, Rusia juga secara khusus memiliki sumber daya alam dan wilayah yang berbatasan dengan laut. Keempat, Rusia juga 
hub komunikasi, informasi dan transportasi yang penting secara global dan berkembang cepat. Keputusan membentuk Eurasian Economic Community (EvrAzEs) tahun 2000 sejalan dengan konsep yang berkembang dalam multi-speed and multilevel integration. Perkembangan inisiatif integrasi kawasan pasca Soviet sejak tahun 1991 dapat dilihat dalam tabel berikut ini.

Tabel 1.

Regional Integration Initiatives and Organizations in the Post-Soviet Space

\begin{tabular}{|c|c|c|}
\hline Initiative / Organization & Participants & General Status \\
\hline CIS (1991) & $\begin{array}{l}\text { Armenia, Azerbaijan, Belarus, } \\
\text { Georgia (withdrew 2008), } \\
\text { Kazakhstan, Kyrgyzstan, } \\
\text { Moldova, Russia, Tajikistan, } \\
\text { Turkmenistan, Ukraine, } \\
\text { Uzbekistan }\end{array}$ & Active \\
\hline Customs Union (1992) & $\begin{array}{l}\text { Belarus, Kyrgyzstan, Tajikistan, } \\
\text { Uzbekistan }\end{array}$ & Abandoned \\
\hline Economic Union (1993) & CIS members (except Ukraine) & Abandoned \\
\hline Free Trade Area (1994) & $\begin{array}{l}\text { CIS members (except Rusia and } \\
\text { Turkmenistan) }\end{array}$ & Relaunched in 1999 \\
\hline $\begin{array}{l}\text { Central Asian Union } \\
\text { (1994) }\end{array}$ & $\begin{array}{l}\text { Kazakhstan, Kyrgyzstan, } \\
\text { Uzbekistan, Tajikistan (joined } \\
\text { 1998) }\end{array}$ & $\begin{array}{l}\text { Renamed Central Asian } \\
\text { Economic Union (1998); } \\
\text { transformed into CACO } \\
(2002)\end{array}$ \\
\hline Customs Union (1995) & $\begin{array}{l}\text { Belarus, Kazakhstan, Russia, } \\
\text { Kyrgyzstan (joined 1997), } \\
\text { Tajikistan (joined 1998) }\end{array}$ & $\begin{array}{l}\text { Transformed into } \\
\text { EvrAzES (2000) }\end{array}$ \\
\hline Shanghai Five (1996) & $\begin{array}{l}\text { China, Kazakhstan, Kyrgyzstan, } \\
\text { Russia, Tajikistan, Uzbekistan } \\
\text { (2001) }\end{array}$ & $\begin{array}{l}\text { Transformed into SCO } \\
\text { (2001) }\end{array}$ \\
\hline GUAM (1997) & $\begin{array}{l}\text { Azerbaijan, Georgia, Moldova, } \\
\text { Ukraine, Uzbekistan (joined } \\
\text { 1999, withdrew 2005) }\end{array}$ & $\begin{array}{l}\text { Active; renamed GUAM } \\
\text { Organization for } \\
\text { Democracy and } \\
\text { Economic Development } \\
\text { (2006) }\end{array}$ \\
\hline Free Trade Area (1999) & $\begin{array}{l}\text { CIS members (except Russia and } \\
\text { Turkmenistan) }\end{array}$ & Relaunched in 2011 \\
\hline $\begin{array}{l}\text { EvrAzES (2000) } \\
\text { (Eurasian Economic } \\
\text { Community) }\end{array}$ & $\begin{array}{l}\text { Belarus, Russia, Kazakhstan, } \\
\text { Kyrgyzstan, Tajikistan, } \\
\text { Uzbekistan, (joined 2006, } \\
\text { withdrew 2008) }\end{array}$ & Active \\
\hline $\begin{array}{l}\text { Shanghai Cooperation } \\
\text { Organization (SCO) } \\
(2001)\end{array}$ & $\begin{array}{l}\text { China, Kazakhstan, Kyrgyzstan, } \\
\text { Russia, Tajikistan, Uzbekistan }\end{array}$ & Active \\
\hline Central Asian & Kazakhstan, Kyrgyzstan, & Merged with EvrAzES \\
\hline
\end{tabular}




\begin{tabular}{|c|c|c|}
\hline Initiative / Organization & Participants & General Status \\
\hline $\begin{array}{l}\text { Cooperation } \\
\text { Organization (CACO) } \\
(2002)\end{array}$ & $\begin{array}{l}\text { Tajikistan, Uzbekistan, Russia } \\
\text { (joined 2004) }\end{array}$ & (2006) \\
\hline $\begin{array}{l}\text { Collective Security } \\
\text { Treaty Cooperation } \\
\text { (CSTO) (2002) }\end{array}$ & $\begin{array}{l}\text { Armenia, Belarus, Kazakhstan, } \\
\text { Kyrgyzstan, Russia, Tajikistan }\end{array}$ & Active \\
\hline $\begin{array}{l}\text { Common Economic } \\
\text { Space (2003) }\end{array}$ & $\begin{array}{l}\text { Belarus, Russia, Kazakhstan, } \\
\text { Ukraine }\end{array}$ & Abandoned \\
\hline $\begin{array}{l}\text { Eurasian Customs Union } \\
(2007)\end{array}$ & Belarus, Russia, Kazakhstan & Active; within EvrAzES \\
\hline Free Trade Area (2011) & $\begin{array}{l}\text { Armenia, Belarus, Kazakhstan, } \\
\text { Kyrgyzstan, Moldova, Russia, } \\
\text { Tajikistan, Ukraine }\end{array}$ & Active \\
\hline $\begin{array}{l}\text { Single Economic Space } \\
(2012)\end{array}$ & Belarus, Russia, Kazakhstan & Active; within EvrAzES \\
\hline
\end{tabular}

Sumber: Rilka Dragneva and Katarryna Wolczuk (Eds), Eurasian Economic Integration : Law, Policy and Politics, Edward Elgar Publishing Limited, Cheltenham, 2013, p. 222-223.

Persepsi Rusia terhadap integrasi Eurasia tampak saat Ukraina berpartisipasi dalam pembentukan Common Economic Space (CES) dengan Rusia, Belarusia dan Kazakhstan, saat Eurasian Economic Community (EurAsEC) juga telah operasional. Sementara itu, Ukraina, Moldova, dan Armenia lebih memilih menjadi status observer dalam Eurasian Economic Community. Namun demikian, dorongan integrasi pada awal tahun 2000-an mengalami kemunduran dengan pengaruh ultra-liberal dalam Pemerintahan Rusia, yang berpandangan bentuk-bentuk integrasi pasca Soviet secara ekonomi tidak efisien. Ide menyatukan kembali ekonomi CIS sebagai common market dan inisiatif integrasi Presiden Vladimir Putin tidak didukung di Rusia. Pada saat yang sama tidak memungkinkan secara simultan membentuk Customs Union dan Common Economic Space di saat mengupayakan keanggotaan World Trade Organization (WTO $)^{4}$ yang dianggap prioritas pada periode tersebut. Hal ini setidaknya menyebabkan proses integrasi terhenti untuk beberapa tahun.

Krisis ekonomi dan keuangan global telah berdampak terhadap pandangan geopolitik Rusia dalam hal integrasi pasca Soviet. Proses globalisasi dan kompetisi global tidak memungkinkan satu negarapun, termasuk Rusia, untuk bertindak sendiri, memaksanya

\footnotetext{
${ }^{4}$ Rusia mengajukan aplikasi ke WTO bulan Juni 1993. Selanjutnya Belarusia mengajukan tanggal 23 September 1993. Sementara itu, Kazakhstan menyampaikan aplikasinya pada tanggal 29 Januari 1996.
} 
mencari sekutu dalam dunia multi polar yang baru. Setidaknya, Rusia berupaya mewujudkan potensi Customs Union dan Common Economic Space Rusia, Kazakhstan dan Belarusia, dengan harapan Armenia, Tajikistan, Kyrgyzstan, Ukraina dan beberapa negara lainnya akan ikut bergabung kemudian. Dalam tahap ini, fokus utamanya maksimalisasi free movement of goods, services, capital and labour. Presiden Vladimir Putin menyatakan integrasi kawasan - seluruh dunia mengikuti jalan ini - upaya yang paling efektif untuk memaksimalkan sumber daya pertumbuhan domestik dan memperkuat daya saing pada pasar global. Kekuatan bersama akan lebih kuat dan lebih mudah untuk menghadapi tantangan global secara bersamasama. $^{5}$

Berdasarkan pertimbangan di atas Eurasian Economic Union dibentuk sebagai "community of equal partners". Eurasia bukanlah sinomim dengan Rusia. Meskipun peran dominan Rusia sebagai ekonomi terbesar di kawasan, Eurasian project ini setidaknya dari sudut pandang politik, tidak dapat berkembang di sekitar Rusia sendiri. Namun demikian, aspek politik integrasi Eurasia tidak mengurangi kepentingan ekonominya. Faktanya, Rusia dengan kekuatan ekonominya harus menawarkan insentif proyek kerjasama dalam "multi-polar club" ini. Rusia memiliki dasar melakukan klaim kepemimpinan

\footnotetext{
5 Sergei Glazyev "Russia and the Eurasian Union", dalam Piotr Dutkiewicz and Richard Sakwa (Eds), Eurasian Integration - The View From Within, Routledge, Oxford, 2015, p. 86.
}

admistratif maupun ideologis dalam membangun Eurasian Economic Union ini. Peran Rusia secara ekonomi dan sejarah yang dominan selalu menjadi faktor penting dalan integrasi Eurasia. Rusia mencakup 87,6\% potensi ekonomi, 78,4\% populasi dan $83,4 \%$ wilayah Eurasian Economic Union, dibandingkan $78,3 \%$ total Gross Domestic Product (GDP), 53,2\% populasi dan 79,3\% wilayah pada kawasan perdagangan bebas CIS. Hal ini memiliki dampak positif dan negatif terhadap proses integrasi ekonomi Eurasia.

\section{Konsep Rusia terhadap Integrasi Eurasia}

\section{Terminologi "Eurasian Integration"} seringkali dimaksudkan terbatas pada integrasi ekonomi antara Rusia, Kazakhstan dan Belarusia. Namun Presiden Vladimir Putin mendeskripsikan sesuatu yang lebih jauh dan ambisius : "We are proposing a powerful supranational association capable of becoming one of the poles of the modern world and serving as an effective bridge between Europe and the dynamic Asia-Pacific region". Tanggal 4 Oktober 2011, Presiden Putin menerbitkan artikel "A New Integration Project for Eurasia : A Future that is Being Born Today" yang menunjukkan sesuatu yang lebih daripada definisi integrasi Eurasia yang bersifat teknis

\footnotetext{
${ }^{6}$ Vladimir Putin, Izvestiya, 4 October 2011. Hal ini kemudian juga banyak dikritik sebagai "revival of Russian great power statehood". Alexei Podberezkin and Olga Podberezkina, "Eurasianism as an Idea, Civilizational Concept and Integration Challenge", in Piotr Dutkiewicz and Richard Sakwa (Eds), Eurasian Integration - The View from Within, Routledge, Oxford, 2015, p. 51.
} 
dan sempit. Bahkan Pemimpin Rusia tersebut melihat Greater Europe sebagai suatu "megaentity" yang memasukkan Uni Eropa dan Eurasian Economic Union sebagai konsep "Greater Eurasia". Pendekatan terhadap ide ini disampaikan Presiden Vladimir Putin pada European Union - Russia Summit tanggal 28 Januari 2014 di Brussel.

Pusat kekuatan global yang sedang berkembang seperti NATO / UE, China dan India memiliki karakter peradaban dan budaya yang berbeda dengan keunikannya masingmasing. Meskipun terdapat pengaruh globalisasi, pusat-pusat tersebut tetap mengembangkan keunikannya dan pengaruhnya terhadap pusat-pusat lainnya. Dalam konteks ini Rusia juga memiliki keunikan tersendiri. Rusia juga dihadapkan pada pilihan apakah menjadi pusat peradaban dan kekuatan ideologis sesuai keunikannya atau berintegrasi dengan salah satu pusat kekuatan yang telah ada dan kehilangan identitasnya. Jika Rusia memilih independen berdasarkan sejarah dan budayanya, Rusia akan mengembangkan dan mengimplementasikan sejumlah kebijakan sesuai sumber daya yang dimilikinya di Eurasia.

Beberapa kemungkinan agenda kebijakan Rusia dalam konteks ini antara lain : Pertama, prioritas percepatan pembangunan kawasan timur Rusia, terutama dalam hal infrastruktur, jaringan transportasi dan potensi human capital dalam membangun kawasan tersebut menjadi pusat politik dan ekonomi Rusia yang kedua dengan kapasitas administratif, keuangan dan ekonomi. Kedua, memajukan integrasi Eurasia dalam segala arah, dari Ukraina dan Kazakhstan hingga Jepang dan China, dan membangun sistem hubungan ekonomi dan politik yang stabil di sekitar Rusia. Ketiga, mempertahankan dan memperluas kontak dengan pusat kekuatan yang telah ada, seperti Uni Eropa dan Amerika Serikat dengan kepentingan Rusia pasca Soviet.

\section{Eurasianisme dalam Konteks Kebijakan} Luar Negeri Rusia

$$
\text { Dokumen yang memformulasi upaya }
$$
dan prinsip kebijakan luar negeri Rusia terhadap integrasi Eurasia pada masa Presiden Vladimir Putin terdapat pada artikel " $A$ New Integration Project for Eurasia - A Future that is Being Born Today", dan "The New Concept of the Foreign Policy of the Russian Federation". ${ }^{7}$ Artikel Putin mengenai integrasi Eurasia tersebut menekankan aspirasi mengintegrasikan kembali eks negara-negara Republik Soviet berdasarkan nilai-nilai baru, dengan fondasi-fondasi ekonomi dan politik yang baru. Putin mengusulkan struktur internasional baru yang dapat menjadi "efective link" antara kawasan Eropa dan Asia Pasifik. Eurasianisme dimaksudkan menjembatani

\footnotetext{
7 Andrei A. Kazantsev, "Eurasian Perspectives on Regionalism : Central Asia and Beyond", dalam Piotr Dutkiewicz and Richard Sakwa (Eds), Eurasian Integration - The View from Within, Routledge, Oxford, 2015, p. 215.
} 
Eropa dan Asia. Lebih lanjut, Putin menyatakan Eurasian Union seharusnya menjadi bagian "Greater Europe" yang disatukan oleh nilai dan norma bersama dan mengusulkan perjanjian perdagangan bebas dan bahkan bentuk integrasi yang lebih maju lagi dengan Uni Eropa. Putin juga mendeklarasikan bahwa Customs Union dan masa depan Eurasian Union seharusnya membantu anggotanya berintegrasi ke Eropa yang lebih luas.

Banyak dokumen kebijakan luar negeri Rusia diformulasikan sesuai dengan artikel Putin tersebut di atas. Dalam "the New Concept of the Foreign Policy of the Russian Federation", yang disetujui Presiden Vladimir Putin tanggal 12 Februari 2013, jelas mengindikasikan bahwa Eurasian Economic Union didasarkan pada prinsip-prinsip hubungan ekonomi yang saling menguntungkan, dan berfungsi sebagai "effective link" antara kawasan Eropa dan Asia Pasifik. Rusia melihat prioritas upaya mewujudkan Eurasian Economic Union tidak hanya untuk memanfaatkan hubungan ekonomi yang saling menguntungkan dalam CIS, tetapi juga menjadi suatu model yang terbuka terhadap negara-negara lain, model yang akan menentukan masa depan negara-negara CIS.

Dunia saat ini mengalami era perubahan yang fundamental. Lingkungan global terbagi-bagi dengan kawasan-kawasan yang diatur sejumlah norma yang berbeda yang berinteraksi dan berkompetisi satu sama lain.
Kemampuan untuk meyakinkan yang lain untuk mengadopsi norma dan kepentingan menjadi syarat untuk keberhasilan seperti usulan AS untuk TTIP dan TPP, termasuk evolusi dan integrasi Eurasia yang diusulkan Rusia. Integrasi Eurasia merupakan ujian yang penting terhadap kemampuan Rusia meyakinkan negara lain berada di pihaknya dengan menggunakan persuasi modern seperti lingkungan bisnis yang atraktif dan peluang yang saling menguntungkan, di luar upayaupaya yang bersifat paksaan.

\section{Peluang dan Tantangan}

$$
\text { Presiden Putin berulangkali }
$$
mengusulkan pembentukan "a continental zone of cooperation" dari Lisbon ke Vladivostok, berdasarkan perdagangan bebas dan interaksi yang saling menguntungkan. Integrasi Eurasia yang lebih luas ini akan menggabungkan Eropa, China dan India serta Timur Tengah. Hal ini dipandang akan mewujudkan peluang penambahan pertumbuhan baru. Upaya Rusia ini tidak hanya akan membutuhkan suatu common market tetapi kerjasama lebih besar dari anggota Common Economic Space (CES) serta common development strategy. Strategi ini tidak hanya tergantung pada Rusia namun juga mempertimbangkan Belarus's Five-Year Development Plans dan Kazakhstan's Industrialization Programme.

Berdasarkan data WTO, terdapat 200 kelompok kawasan dengan tingkat integrasi ekonomi berbeda-beda. Proyek integrasi yang 
dipandang berhasil adalah European Union (EU), North American Free Trade Agreement (NAFTA), the Association of Southeast Asian Nations (ASEAN), the Southern Common Market (Mercosur) dan the Andean Community of Nations. Semua kelompok kawasan ini berada pada tingkat integrasi ekonomi yang berbeda-beda, dengan format integrasi free trade zones, customs union, common market and economic and monetary union. Perbandingan kelompok-kelompok kawasan tersebut dapat dilihat dalam tabel berikut ini.

Tabel 2.

Major Regional Alliances in the Global Economy

\begin{tabular}{|l|c|c|c|c|}
\hline & $\begin{array}{c}\text { Share of } \\
\text { Global } \\
\text { Exports, } \\
\text { \% }\end{array}$ & $\begin{array}{c}\text { Share of Global } \\
\text { GDP (by } \\
\text { Purchasing } \\
\text { Power Parity), } \\
\text { \% }\end{array}$ & $\begin{array}{c}\text { Mutual } \\
\text { Exports, } \\
\text { \% }\end{array}$ & $\begin{array}{c}\text { Population, } \\
\text { million people }\end{array}$ \\
\hline ASEAN (1967) & 6.0 & 4.0 & 25.0 & 591 \\
\hline NAFTA (1988) & 21.0 & 24.0 & 51.0 & 445 \\
\hline Mercosur (1991) & 1.8 & 4.0 & 14.0 & 273 \\
\hline $\begin{array}{l}\text { Andean Community } \\
\text { of Nations (1969) }\end{array}$ & 0.6 & 1.0 & 8.0 & 111 \\
\hline $\begin{array}{l}\text { EU-27, without } \\
\text { Croatia (Eurozone-12) } \\
\text { (1957) }\end{array}$ & 38.0 & 21.0 & 68.0 & 499 \\
\hline $\begin{array}{l}\text { Customs Union } \\
\text { (2007) }\end{array}$ & 3.0 & 3.0 & 12.5 & 167 \\
\hline
\end{tabular}

Sumber: Sergei Glazyev, "Russia and the Eurasian Union", dalam Piotr Dutkiewicz and Richard Sakwa (Eds), Eurasian Integration - The View From Within, Routledge, Oxford, 2015, p. 91.

Perkembangan rencana Trans-Pacific Partnership $\quad(\mathrm{TPP})^{8}$ dan $\quad$ US-EU

8 Trans-Pacific Partnership (TPP) adalah trade agreement yang disepakati tanggal 5 Oktober 2015 antara 12 negara di Asia Pasifik - tidak termasuk China. Proposal akhir ditandatangani tanggal 4 Februari 2016 di Auckland, Selandia Baru, setelah proses negosiasi 7 tahun. Saat ini dalam proses ratifikasi sebelum dinyatakan berlaku. Perjanjian ini meliputi 30 chapters yang bertujuan untuk "promote economic growth; support the creation and retention of jobs; enhance innovation, productivity and competitiveness; raise living standards; reduce poverty in the signatories' countries; and promote transparency, good governance, and enhanced labor and environmental protections". TPP merupakan perluasan dari Trans-Pacific Strategic Economic Partnership Agreement (TPSEP atau P4) yang ditandatangani Brunei, Chile, Selandia Baru, dan Singapura tahun 2005. Pada tahun 2008, Australia, Kanada, Jepang, Malaysia, Mexico, Peru, Amerika Serikat, dan Vietnam, bergabung dalam negosiasi hingga menjadi 12 negara. Bagi Pemerintah AS, TPP awalnya merupakan "companion agreement" terhadap Transatlantic Trade and Investment Partnership (TTIP), perjanjian perdagangan antara AS dengan UE. Namun sejal terpilihnya Donald J. Trump sebagai Presiden AS dan dilantik tanggal 20 Januari 2017, dengan US Presidential Memorandum tertanggal 23 Januari 2017, AS secara resmi keluar dari 
Transatlantic Trade and Investment Partnership (TTIP) ${ }^{9}$ pada awalnya akan juga mempengaruhi perkembangan Eurasian Economic Union. Kemunculan zona perdagangan bebas baru ini akan merekonfigurasi global economic space beberapa tahun ke depan. Hal ini akan menjadi tantangan bagi eksportir CES terhadap super blok tersebut. Kesepakatan zona perdagangan bebas UE-AS juga akan memberikan hambatan serius bagi tujuan

negosiasi dan perjanjian TPP. Memorandum Presiden AS tersebut dapat diunduh pada https://www.whitehouse.gov/the-pressoffice/2017/01/23/presidentialmemorandum-regarding-withdrawal-unitedstates-trans-pacific. Diakses tanggal 12 Februari 2017.

9 Tanggal 12 Februari 2013, Presiden AS Barack Obama dalam State of the Union menyampaikan inisiatif Transatlantic Trade and Investment Partnership (TTIP). Hari berikutnya, Presiden Komisi Eropa Jose Manuel Barroso mengumumkan bahwa proses negosiasi TTIP akan dimulai. TTIP adalah trade agreement antara Uni Eropa dengan Amerika Serikat, dengan tujuan mempromosikan perdagangan dan pertumbuhan ekonomi multilateral. Pemerintah AS memandang TTIP merupakan "companion agreement" dengan Trans-Pacific Partnership (TPP). TTIP dengan 24 chapters masih dalam proses negosiasi yang meliputi : market access, regulatory cooperation, rules, and institutional / modes of cooperation. AS dan UE bersama-sama mewakili $60 \%$ dari global GDP serta $33 \%$ perdagangan barang dan $42 \%$ perdagangan jasa di dunia. Perdagangan bebas keduanya akan merupakan perjanjian perdagangan bebas kawasan yang terbesar dalam sejarah yang meliputi $46 \%$ GDP dunia. mewujudkan zona perdagangan bebas UE-Rusia. Hal ini juga akan berdampak terhadap perluasan integrasi ekonomi pasca Soviet. Perkembangan baru dengan keluarnya AS dari negosiasi dan perjanjian TPP tersebut semakin membuka peluang bagi Rusia guna memanfaatkan peluang yang ada guna menjalin konektivitas ke kawasan Asia pada umumnya.

Interdependensi ekonomi di Asia Timur $^{10}$ berkembang dari jaringan produksi kawasan yang berpusat pada Jepang yang disebut banyak pihak sebagai "de facto economic integration", dan kemudian kebangkitan ekonomi China yang menyebabkan konflik kawasan yang berskala besar akan sangat merugikan banyak pihak. Keputusan AS untuk mengimplementasikan "strategic turn" ke arah Asia Pasifik yang merupakan salah satu tujuan kebijakan luar negeri AS yang penting, yang oleh mantan Menteri Luar Negeri AS Hillary Clinton

10 Asia Timur dalam artikel ini merujuk pada kawasan yang terdiri dari Brunei Darussalam, Kamboja, China, dan Far Eastern Region Rusia seperti Indonesia, Laos, Malaysia, Myanmar, Korea Utara, Filipina, Singapura, Korea Selatan, Thailand dan Vietnam. Konteks Asia Timur ini dipandang dalam perspektif akademisi Rusia. Lihat Ekaterina Koldunova,"Russia's Involvement in Regional Cooperation in East Asia : Opportunities and Limitations of Constructyive Engagement". Asian Survey. Vol. 56. Number 3, p. 532. 
dalam artikelnya tahun 2011, "America's Pacific Century" menjadikan kawasan ini proyek baru yang dikenal dengan Trans-Pacific Partnership (TPP). ${ }^{12}$ Kebijakan ini juga dikenal sebagai US "pivot" to Asia. ${ }^{13}$ Latar belakang ini juga yang menyebabkan Rusia mengambil langkah atau sikap lebih pro aktif terhadap

11 Hillary Clinton, "America's Pacific Century", Foreign Policy (November 2011), <http://foreignpolicy.com/2011/10/11/ameri cas-pacific-century.

12 Dapat diunduh pada https://csisprod.s3.amazonaws.com/s3fspublic/legacy_files/files/publication/120413 _gf_glaser.pdf. Diakses tanggal 8 November 2016.

${ }^{13}$ Pada bulan November 2011, Menteri Luar Negeri Amerika Serikat Hillary Clinton menjelaskan kepada publik "US pivot to Asia" pada era Presiden Barack Obama. Mengingat banyaknya kritik terhadap terminologi "pivot" Pemerintah AS menyatakan kebijakannya adalah upaya untuk "rebalance" strategi AS ke Asia. Walaupun AS telah memusatkan perhatiannya pada kawasan Asia Pasifik sebelumnya, kebijakan ini menekankan pada pergeseran kebijakan luar negeri AS yang menyebutkan abad ke-21 akan menjadi "America's Pacific Century". Apa yang disebut sebagai "rebalancing strategy" ini akan meningkatkan investasi AS di kawasan Asia Pasifik melalui saluran diplomatik, ekonomi dan strategis, dimana pada saat yang sama mendukung pengembangan keamanan kawasan yang lebih berkelanjutan dan arsitektur ekonomi untuk mempromosikan stabilitas dam kesejahteraan di kawasan. Dapat diunduh pada https://csisprod.s3.amazonaws.com/s3fspublic/publication/140428_Conley_Transatl anticPolicyAsiaPacific_Web.pdf. Diakses tanggal 8 November 2016. institusi regional. Dalam satu dekade terakhir, Rusia lebih mendasarkan pada ikatan bilateral di kawasan, terutama dengan China. Rusia sebelumnya lebih bersifat low profile dalam kerjasama multilateral di Asia Timur. Keanggotaan Rusia pada APEC dimulai sejak 1998. Namun, Rusia menjadi lebih aktif menjadi bagian yang terintegrasi dari seluruh jaringan institusi kawasan mulai sejak tahun 2005 dan menjadi tuan rumah APEC Summit tahun 2012 di Vladivostok setelah terjadinya krisis ekonomi global 2008-2009 dan kepentingan kerjasama regional bagi Rusia memperoleh bentuk yang lebih jelas.

Inisiatif Rusia untuk menjadi tuan rumah APEC tahun 2012, agenda Rusia dalam mitra dialog ASEAN dan inisiatif Russia - ASEAN Summit tahun 2016 serta proyek kawasan dalam bidang energi, infrastruktur menunjukkan contoh-contoh jelas kontribusi terkini Rusia terhadap kerjasama multilateral di Asia Timur. Sementara sanksi Barat terhadap Rusia setelah krisis Ukraina tahun 2014 memperkuat upaya keterlibatan Rusia untuk lebih dekat dengan Asia Timur. TPP mungkin tidak menjadi ancaman serius bagi Rusia dalam jangka menengah, namun dalam jangka panjang, upaya promosi integrasi 
ekonomi di kawasan Asia Pasifik tanpa Rusia, seperti halnya TPP akan berdampak terhadap kepentingan Rusia di kawasan. Jika China bergabung dengan TPP misalnya, hal ini akan menyebabkan Rusia menjadi lebih tidak menarik bagi mitra-mitra Asia sebagai partner ekonomi dan politik. Hal ini tentunya akan juga menjadi pertimbangan bagi Rusia dalam memperkuat posisi Rusia dalam perdagangan internasional dan ekonomi global, termasuk memperluas kerjasamanya dengan kawasan lain, seperti Asia Tenggara ${ }^{14}$ pada masa yang akan datang.

Perkembangan posisi Rusia dalam kerjasama kawasan Asia Timur masih memiliki banyak tantangan yang serius. Faktor domestik Rusia akan sangat menentukan terkait upaya meningkatkan hubungan ekonomi Rusia ke arah timur. Setidaknya fokus integrasi ekonomi di kawasan Siberia

14 Dalam ASEAN Summit di Sochi tahun 2016, Rusia telah mengusulkan ide kemitraan ekonomi antara ASEAN, Shanghai Cooperation Organozation (SCO) dan Eurasian Economic Union. Inisiatif lain yang terkini adalah adalah Eastern Economic Forum, pertemuan tahunan kalangan bisnis dari Rusia dan negaranegara Asia Timur, yang dimulai di Vladivostok sejak tahun 2015 yang bertujuan menarik lebih banyak perhatian ke kawasan Rusia dari kalangan bisnis Asia Timur. dan kawasan Rusia lainnya di arah yang disebut "Far East" Rusia masih perlu dikembangkan guna memiliki tingkat yang sama dengan negara Asia Timur lainnya, khususnya China dan Jepang serta Korea Selatan. Kemudian Rusia juga harus menyelesaikan masalah krusial lainnya untuk mengatasi persepsi bahwa Rusia secara geografis adalah bagian dari Asia Timur, namun secara ekonomi dan politik masih dipandang merupakan "external player" di kawasan.

Krisis di Ukraina tahun 2014 telah menyebabkan dijatuhkannya sanksi Barat terhadap Rusia dan menjadikan Rusia berorientasi ke arah Asia Timur. China kemungkinan besar masih merupakan arah kunci dari reorientasi ini dan aspek hubungan di bidang energi menjadi fokus utamanya. Pertanyaannya adalah sampai sejauh mana reorientasi ke arah Asia Timur ini akan melibatkan organisasi kerjasama regional. Proyek integrasi Eurasia akan tetap menjadi prioritas utama dalam kerjasama regional. Namun demikian, tingkat kesesuaian antara Eurasian Economic Union dan proses integrasi regional Asia Timur masih belum jelas, dimana Free Trade Area (FTA) antara Eurasian Economic Union dan Viet Nam masih satu-satunya implementasi dari bidang ini. Pertanyaan lainnya adalah apakah 
Rusia dan China akan mampu melakukan koordinasi tindakannya dalam institusi regional di Asia Timur, dimana dalam dekade terakhir China memainkan peran yang lebih proaktif daripada Rusia. Melihat kontradiksi AS - China dan hubungan Rusia saat ini dengan Barat, China kemungkinan akan mendorong Rusia untuk mengimbangi AS di Asia Timur, dimana situasi ini dengan sangat hati-hati akan dihindari Rusia. Setidaknya China tidak ingin pesaing lain dalam hubungannya dengan negara-negara di kawasan tersebut. China tidak ingin melakukan koordinasi tindakannya di Asia Timur dengan negara ketiga. Tahun 2013 China memulai inisiatif makro regionalnya, One Belt, One Road (OBOR), ${ }^{15}$ yang bertujuan menciptakan kondisi ekonomi yang menguntungkan bagi China di Asia Tengah dan Asia Tenggara dan

${ }^{15}$ Silk Road Economic Belt dan the 21stcentury Maritime Silk Road, juga dikenal sebagai The Belt and Road (B\&R), atau One Belt, One Road (OBOR) atau the Belt and Road Initiative sebagai suatu kerangka dan strategi pembangunan, yang diusulkan oleh Presiden China Xi Jinping yang memusatkan pada konektivitas dan kerjasama, khususnya negara-negara di antara RRT dan kawasan Eurasia, yang terdiri atas dua komponen utama, "Silk Road Economic Belt" dan "Maritime Silk Road". Strategi ini menekankan upaya China mengambil peran lebih besar dalam urusan-urusan global, dan kepentingan untuk prioritas kerjasama di bidang seperti steel manufacturing. Inisiatif ini disampaikan pada bulan September dan Oktober 2013. berpotensi menjadikan upaya Rusia di dalam kerjasama Asia Timur berada pada posisi pinggiran.

\section{Penutup}

\section{Integrasi Eurasian Economic} Union masih konsisten dengan norma internasional secara umum dalam asosiasi ekonomi kawasan. Meskipun dalam perspektif Cold War kemunculan Eurasian Economic Union juga dikritisi oleh Amerika Serikat sebagai penciptaan kembali versi baru dari Union of Soviet Socialist Republics (USSR) dalam bentuk integrasi ekonomi. Latar belakang historis, tradisi budaya dan kepentingan geopolitik, masih menempatkan Rusia sebagai "natural centre" dari proses integrasi Eurasian Economic Union. Eurasian integration project akan mungkin diwujudkan jika Rusia menjadi "point of attraction" dan menjadi model dari "effective governance". Keuntungan ekonomi bagi negara anggota Eurasian Economic Union akan terbatas apabila tidak dilakukan reformasi struktural dan institusional yang diperlukan guna mencapai tujuan yang diharapkan dari Eurasian Economic Union. Hal ini akan sangat dipengaruhi oleh sejauh mana Rusia dengan ambisi geopolitiknya menggunakan Eurasian Economic Union untuk kepentingannya dan sejauh 
mana Rusia menggunakan kepemimpinannya dalam mendorong terwujudnya reformasi di negara-negara anggota Eurasian Economic Union guna mewujudkan integrasi ekonomi dan politik yang sesungguhnya. Hal tersebut akan menuntut perubahan radikal dalam kebijakan ekonomi Rusia dan mewujudkan suatu model yang atraktif terhadap pembangunan, kerjasama internasional, kesejahteraan sosial dan migrasi serta perluasan Eurasian Economic Union pada masa yang akan datang, termasuk upayanya bermitra dengan entitas regional lainnya di kawasan seperti ASEAN.

Situasi keseluruhan pada tahun 1990-an mengindikasikan aktor regional menyambut baik masuknya Rusia secara bertahap dalam institusi regional. Setidaknya terdapat tiga alasan dalam konteks ini. Pertama, sejak periode bipolar, saat Rusia masih merupakan bagian dari konstelasi kekuatan regional, Rusia jelas tidak menunjukkan ekonomi yang kuat. Rusia yang lemah bukan merupakan kompetitor bagi China atau Jepang, maupun kekuatan ekonomi regional serta bagian dari institusi regional. Kedua, baik China dan Jepang bahkan memperoleh manfaat dari strategi ini - akses lebih baik terhadap pasar Rusia, akibat kerjasama yang lebih erat dalam kerangka APEC. Ketiga, dengan mengundang Rusia dalam mitra dialog, ASEAN memperkuat dukungan internasional terhadap posisinya di kawasan. Lebih lagi, sentralitas ASEAN dalam jaringan institusi kawasan. Selain itu sentralitas ASEAN menjadi penengah dalam jaringan institusi kawasan dan menjadi dasar keterlibatan Rusia dalam struktur regional.

Secara domestik Rusia diharapkan menaruh perhatian lebih besar pada proses multilateral, daripada kemitraan bilateral Rusia yang dilakukan selama ini. Keterlibatan Rusia dalam kerjasama kawasan menghadapi beberapa keterbatasan dan tantangan, yang berasal dari tindakan Rusia yang tidak konsisten dalam organisasi regional dan konstelasi yang kompleks dari kekuatan yang berkembang di Asia Timur dalam dua dekade terakhir ini. Hubungan yang mengalasmi setback dengan Barat, telah mendorong interaksi dengan China tampak menjadi aspek kunci dari arah Rusia ke Timur, meninggalkan proses multilateral sebagai opsi kedua.

Selain itu, Rusia juga berbeda dengan regional players lainnya. Rusia bukan merupakan bagian dari production networks yang menjadi fondasi dari regionalisme Asia Timur dan de facto integration. Rusia juga 
bukan merupakan bagian dari konflik politik keamanan yang serius dengan negara di kawasan. Rusia mendukung agenda modernisasi, yang dipandang penting bagi negara di Asia Timur, dan siap mengusulkan inisiatif ekonomi yang menyediakan kawasan pertumbuhan ekonomi baru. Namun demikian, untuk mengimplementasikan inisiatif regionalnya dan menjadi visible

\section{Referensi}

Conley, Heather A., James Mina and Phuong Nguyen. 2016. A Rebalanced Transatlantic Policy toward the Asia-Pacific Region. Washington, D.C. : Center for Strategic and International Studies (CSIS).

Dragneva, Rilka and Katarryna Wolczuk (Eds). 2013. Eurasian Economic Integration : Law, Policy and Politics. Cheltenham : Edward Elgar Publishing Limited.

Dutkiewicz, Piotr and Richard Sakwa (Eds). 2015. Eurasian Integration - The View From Within. Oxford : Routledge.

Franklin, Daniel and John Andrews (Eds). 2012. Megachange : the World in 2050. London : The Economist and Profile Books Ltd.

Friedman, George. 2012. The Next Decade : Empire and Republic in A Changing World. New York : Anchor Books. player di institusi multilateral regional, Rusia harus mengatasi keterbatasan domestik dan internasionalnya. Alienasi dari Barat saat ini dan semakin tumbuhnya ketergantungan terhadap China mungkin pada akhirnya akan mendorong Rusia untuk lebih aktif mencari jalan yang lebih baik dalam upaya mewujudkan misi tersebut.

Glazyev, Sergei. 2015. "Russia and the Eurasian Union", dalam Piotr Dutkiewicz and Richard Sakwa (Eds), Eurasian Integration - The View From Within. Oxford : Routledge.

Kazantsev, Andrei A. 2015. "Eurasian Perspectives on Regionalism : Central Asia and Beyond", dalam Piotr Dutkiewicz and Richard Sakwa (Eds), Eurasian Integration - The View from Within. Oxford : Routledge.

Khanna, Parag. 2016. Connectography : Mapping the Global Network Revolution. London : Weidenfeld \& Nicolson.

Kouldunova, Ekaterina. 2016. "Russia's Involvement in Regional Cooperation in East Asia : Opportunities and Limitations of Constructive Engagement". Asian Survey. Vol. 56. Number 3, pp. 532-554. . 2015. "Russia as a Euro-Pacific Power : Dilemmas of Russian Foreign Policy DecisionMaking”. International Relations. Vol. 29 (3), pp. 378-394. 